\title{
System of technological support for continuous environmental education (by the example of the Altai republic)
}

\author{
Elena Arbusova ${ }^{1, *}$, Roman Oparin ${ }^{2}$, Anatoliy Petrov $^{3}$ and Tatjana Efimova ${ }^{1}$ \\ ${ }^{1}$ Moscow Region State University, 10A, Radio str, 105005, Moscow, Russia \\ ${ }^{2}$ Novosibirsk Pedagogical University, 28, Vilyuiskaya str, Novosibirsk, Russia \\ ${ }^{3}$ Gorno-Altaisk State University, 1, Lenkina str, Gorno-Altaisk, Russia
}

\begin{abstract}
This paper presents a concept of continuous environmental education that has a generic nature but was considered in the context of one particular region - the Republic of Altai. The work also presents a structural-functional model of the system of technological support of the continuous environmental education of secondary school students. The model of the system mentioned above is based on the results of theoretical, methodological and practical research as well as on its experimental verification. The system is based on the principle of environmental education with its substantive, regulatory and procedural functions. The study has confirmed the assumption about the necessity of this concept and proved its effectiveness in terms of developing a technology for continuous environmental education in the region. This concept was adopted by the Government of the Altai Republic and became the theoretical and methodological basis of this technology. The concept of environmental education in the Republic of Altai proposed allows observing the entire educational process and taking into account the connections between all functional structures most fully, since all of them are based on systematic, activity, reflexive, synergetic, resource, cultural approaches. The concept creates a theoretical basis for solving an important practical problem - the scientific substantiation of the didactic basis of environmental education. The investigation performed helps explain the essence and predict the development of complex processes in the field of education. The research allows using the experience of theoretical substantiation of the introduction of didactic provisions to the rank of teaching principles and experience in developing their "instrumentality" (the method of application) in the form of content, normative and procedural didactic functions. Also, this research allows building a concept that creates a theoretical basis for solving important practical problems in the education system and using the experience of revealing the deeper content of previously known pedagogical concepts, enabling the identification of their new core features.
\end{abstract}

\footnotetext{
* Corresponding author: 89236613134@inbox.ru
} 


\section{Introduction}

At the beginning of the third Millennium, the problems of interaction between society and nature became more acute and global. The growing environmental tension in the world has forced the society to think hard about the possibilities of getting out of the current critical situation. One of the most promising options for resolving the crisis is the transition of modern civilization from a technocratic model to a model of sustainable ecological and economic development, proposed in 1992 at the UN International conference in Rio de Janeiro and recognized by 172 countries [1]. However, according to several scientists (D. Meadows, V. P. Kaznacheyev, L. Mathieu, F. Major, G. V. Platonov, etc.), sustainable development of civilization is impossible without an effective strategy in the field of education. Domestic and foreign scientists (G. D. Azroyants, O. Leopold, N. N. Moiseev, A.D. Ursul, J. Forester, etc.) note that the important conditions for educating a person capable of solving the problems of civilization are not only the formation of a complex of knowledge in the field of ecology, but also the development of environmental culture. In their opinion, this is the main task of environmental education. In our opinion, this urgent problem requires further research, especially in terms of technological support. Without solving this problem, continuity in the formation of necessary competencies in the practice of preschool, primary (junior school), general (secondary school), additional, higher education and postgraduate education is disrupted. The educational process occurs spontaneously, without a sufficiently complete and deep substantiation of the methodological, theoretical, and technological foundations of environmental education.

Analysis of the literature shows that the problem of theoretical and methodological substantiation of technological support for continuous environmental education remains poorly developed. In addition, this problem has recently been updated in terms of its specific features related to the regional aspect. The regional aspect in continuous environmental education is considered by N. M. Alirzaev, D. R. Karimova, V. S. Nagaev, V. G. Ukanev, E. D. Shevlyakov, and others. These researchers, analyzing the natural and climatic, socio-economic, cultural, and historical features of the regions of our country, recommend the development of environmental and educational programs taking into account the national and regional component. Gorny Altai, geographically coinciding with the administrative division of the Russian Federation "Republic of Altai", is characterized by unique natural and climatic conditions, has a rich species and resource potential. The fact of recognition of the Altai Mountains as a standard of landscape and biological diversity on a global scale was confirmed by the inclusion of five of its territories - the Altai, the Katunsky nature reserves, Teletskoye lake, the Ukok plateau and mount Belukha - in the list of UNESCO world natural heritage sites [2]. This high status of the Altai mountains determined the development and adoption at the national level of the concept of sustainable development of the region, one of the priorities of which is the environmental education of the population. In accordance with this concept, environmental education implies an effective system for the formation of knowledge and skills in the field of ecology and nature protection, focused on the conservation and rational use of natural resources of the Altai Republic. In addition, the region has developed the "Concept of national schools of the Altai Republic", which is adopted as a basic educational document and forms the basis of the Republican program for the development of education. It highlights the section "Environmental education", which aims to implement a process of continuous learning, education, education in the field of ecology and environmental management. However, improving the effectiveness of existing environmental education practices in the region is not possible without a system of appropriate technological support. The most important components of such support are not only organizational and pedagogical aspects, but also theoretical, methodological, and practical, which remain largely undeveloped to date. 
Our theoretical analysis of the situation of the problem of technological support for environmental education revealed a few significant contradictions, the resolution of which contributed to the achievement of the research goals:

- between the need to improve the effectiveness of continuous environmental education and the inability to achieve this in the absence of a system of appropriate technological support.

- between the obvious relevance and state importance of the problem of environmental education and the lack of elaboration of its system-epistemological aspects in theoreticalmethodological and scientific-methodical research.

- between the methodological development of the problem of continuous environmental education and the low result of its practical solution due to the lack of environmental education technology.

- between the need to develop a pedagogical technology for continuous environmental education in the region and the lack of an appropriate science-based concept of education.

The need to resolve contradictions ensures the relevance of the research and its scientific problem, which consists in finding answers to the following questions. Why the practice of implementing education directly focused on the formation and development of environmental culture, is at an unsatisfactory level, despite the fact that scientists, teachers and practitioners have proven the feasibility and necessity of environmental education? What aspects of the existing concept of environmental education require improvement or fundamental changes? Is the theory of environmental education sufficiently developed and is it didactically secured? What should be the content of the technology of environmental education and the system of technological support for continuous environmental education, focused on the formation and development of environmental culture of students?

The importance and relevance of this issue was the basis for determining the purpose of research - theoretical substantiation and development of the concept of continuous ecological education, pedagogical technology of continuous ecological education and appropriate system technological support of continuous ecological education in the Republic of Altai.

In accordance with the purpose and the hypothesis of the study, the following tasks were formulated:

to systematize the main approaches to determining the content and essential characteristics of environmental education, to substantiate the principle of environmental education as the leading principle of general education.

to substantiate theoretically and to develop the concept of continuous environmental education.

to develop a technology for continuous environmental education and to design a system for technological support of continuous environmental education in the Altai Republic.

to substantiate the implementation of systems ensuring continuous environmental education, to create educational-methodical complex, including package software and regulatory documents, the complex means of managing the implementation of continuous ecological education, scientific-methodical recommendations on organization of independent work of participants of educational process, a set of techniques governing the conduct of the current, final and final evaluation of students.

to test experimentally the level of ecological culture of the participants of continuous environmental education, which determines the efficiency of technological support of ecological education in the Republic of Altai, developing criteria and levels of its formation, allowing to correct systemic implementation process of continuous ecological education taking into account national and regional dimension and its ethno-cultural component.

As part of our research, the concept of continuous environmental education, which has a 
universal character, was developed, and presented, which was implemented on the example of a specific region - the Republic of Altai. Its development is explained in our work by the following circumstances.

Due to the fact that the ecological culture in general in any state, including Russia, is not adequate to the ecological situation of nature, we considered it necessary to work on our own concept of environmental education, and not just refer to documents that have already formulated general theoretical provisions and guidelines. This decision can be explained by the following circumstances: first, it makes it possible to determine the general direction and orientation of the research; second, to select relevant for this research provision, to place the appropriate emphasis; third, it allows to define leading factors of development of the studied object; fourth, to discover which aspects of the existing concept of environmental education in need of improvement or radical changes; fifth, to understand why, despite the fact that scientists, teachers and practitioners have proved the feasibility and necessity of environmental education, the practice of implementing education directly focused on the formation and development of environmental culture is at an unsatisfactory level. All this together makes it possible to get not only practical results, but also to make theoretical increments and conclusions.

We presented the Concept as a system of ideas, views, attitudes that should serve as a starting theoretical base, a strategic reference point for a specific search, which, if mediated and tested by practice, can turn into a theory. The Concept in our work is a methodological and theoretical basis for research activities and contains a grain of transformation thoughts about how to solve the problem posed in the work. It contains methodological guidelines, theory positions, and the constructive part - directions and ideas of transformation.

It was important for us to build a Concept that is general in nature, covers the basic ideas, so that then by deduction we can build private Concepts of environmental education that take into account the specifics of the regions, but do not lose the conceptual provisions and principles.

To achieve this goal, it was necessary to find didactic grounds for effectively solving the problems of environmental education. On this path, it was necessary to analyze the principles of didactics that allow us to solve modern problems of environmental education. On the other hand, in order to implement the didactic principles, it was necessary to create an ecological cultural and educational environment in schools and involve all students in appropriate activities that motivate them to form and develop environmental culture and thinking, as well as to create a system of technological support for the entire process of environmental education of schoolchildren.

The concept of continuous environmental education can play the role of a systemforming factor in modern education, since it is based on a systematic cognitive approach, includes basic principles that allow us to identify system-forming relationships, to establish system-wide properties, to detect and characterize internal and external relationships, sources and conditions of development and self-development of the object under study.

These principles are: 1) the principle of consistency, since it allows you to design complex objects considered as a certain set of elements, the relationship of which determines the integral properties of this set. At the same time, the main emphasis is on identifying the variety of connections and relationships that take place both inside the object under study and in its relationships with the external environment. The properties of the object considered as a whole system are determined not only by summing the properties of its individual elements as properties of its structure, a special strategic, integrative relationships of the object. An important feature of the system approach is that not only the object, but also the research process itself acts as a complex system, the task of which is to connect various object models into a single whole. Its essence is to implement the 
requirements of general systems theory, according to which every object in the process of research should be seen as a large and complex system and, simultaneously, as an element of a more general system; 2) the principle of continuity, as, first, "continuity is a condition of generalization..." [3] and, second, the "continuity at the system level (given the integrity) is manifested as the principle of construction of this system" [4], and finally, the continuity incorporates all the basic essential characteristics of the categories of development. In addition, the dynamic aspect of the continuity principle allows us to perform a reasonable "ascent" to a higher level of theorizing, which is achieved by "deploying a ladder of models connected to each other by a system of asymptotic relations" [5];3) the principle of intersubject relations, as it is expressed in the awareness of the subject in the general system of Sciences, the system of scientific knowledge and in the construction of systematic generalized knowledge, taking into account the links between individual disciplines, theories, scientific understanding of the world, allowing to restore the unity of the world and form integrative thinking.

\section{Methods}

Environmental education, being a complex, highly social, complex, developing, multidimensional concept, claims, in our opinion, to be a fundamental pedagogical category. Indeed, environmental education in pedagogy is not an element of education, but the education itself, which in its content becomes ecological with a recognized need.

The problem of environmental education should be studied in several aspects: methodological, philosophical, and sociological, natural science, psychological and pedagogical, and others. The degree of development of the problem of environmental education can be judged by the discussion issues that are understood in the scientific literature.

At the same time, methodological research plays a special role since the methodology itself has a normative component and its important task is the theoretical understanding and methodological support of research work. This kind of scientific study of the problem is ahead of the educational practice, allows you to transform and improve it. In our case, the methodology of pedagogical ecology as a science becomes practice oriented. The synthesis of scientific concepts with the practice of developing pedagogical systems allows us to build innovative activities to improve modern education in a more meaningful way.

In our research we distinguish several levels of methodology: 1) philosophical knowledge; 2) general scientific methodology (system approach, activity approach, characteristics of various types of scientific research; 3) specific scientific methodology, i.e. a set of methods and research principles applied in a particular special discipline. The methodology of special science includes both problems specific to scientific knowledge in this field, and questions of previous levels. If you keep in mind the whole area of science called "methodology of pedagogical ecology", it is possible, in our opinion, to formulate the definition: methodology of pedagogical ecology is a system of ideas about the foundations and the structure of the relevant theory, the principles of approach and ways of collecting and organizing knowledge that reflects the pedagogical reality, taking into account the significance of greening education and knowledge of the principles of information gathering, analysis and synthesis, the rationale for the proposed research and the evaluation of its results.

The theoretical foundations of pedagogical ecology formulated by us [6] can become the basis for the formation of the methodology of the anthropo-ecological model of environmental education, based on the understanding of the fact that the further development of humanity can take place only together with the further development of nature, its diversity and richness. In this formulation, the anthropo-ecological approach is 
almost equivalent to the statements of classical pedagogy and goes back to Montaigne, Rousseau, Pestalozzi, who argued that the goal of education is to harmonize their relations with nature - internal (their own biological) and external (the natural environment), and through this - to gain freedom from the harmful influence of civilization.

At the same time, in our opinion, the fundamental foundations of the anthropoecological model of environmental education need to use the methodological functions of philosophy, which are manifested in the analysis of the fundamental concepts of environmental pedagogy, without which it is impossible to build a theoretical system of any special science. The general and final goal of environmental education, as we believe, is the formation of an environmental culture of the individual at the philosophical level, reflecting the measure of possession of environmental knowledge and understanding of reality. At the philosophical level, personal culture involves: 1) the interpretation of environmental problems at the level of philosophy; 2) the ability to navigate the main directions of philosophy and types of philosophizing; 3 ) the ability to think dialectically; 4) the ability to analyze environmental problems. This also implies the main methodological tasks of environmental education: 1) formation of a scientific and philosophical view of the world and the place of man in it; 2) introduction to the world's philosophical culture as a universal value; 3 ) formation of the ability to independently and creatively solve philosophical and methodological problems related to ecology.

The conditions that determine the content of the fundamental foundations of the anthropo-ecological model of environmental education, in our opinion, can be considered at three closely interrelated levels of formation of its content: 1) civilizational-global; 2) national-state and 3) subject.

Civilization and global level determination assumes compliance with the principles 1) humanization (of human-orientation and humanitarian values); 2) strengthening (taking into account the universal, cosmopolitan knowledge); 3) the priority of universal values over group values (orientation to human ideals, goals, and cultural values); 4) pluralism (taking into account diversity of points of view).

The national-state level includes the following principles: 1) pragmatism (orientation of education to the requirements of society and a certain person); 2) continuity and originality in the development of the national system of environmental education (taking into account national traditions, values, norms and ideals of modern Russian society).

The subject level of determination of the content of environmental education is the deepest level. The methodological basis for the formation of the content of environmental education at this level consists of 1) the principle of compliance of the content of environmental education with the specifics of the subject of ecology (comparison of the content of educational environmental material with the level of development of this science in this historical period); 2) the principle of consistency, integrity, and availability (compliance in structure, content, volume and methods of teaching, age, level of fitness and cognitive abilities of the learners); 3 ) the principle of flexibility (taking into account specifics of the region, natural resources, peculiarities of a particular institution); 4) the principle of active orientation (communication of requirements to knowledge and skills of learners, content of their activities).

Concretizing the scope of our vision of the anthropo-ecological concept of environmental education in general, and technological support for continuous environmental education in particular, based on the theory of semantic fields, the semantic matrix and the problem field of our research were developed.

The semantic matrix of a scientific problem according to L. M. Bosova is a system of analysis (semantic, logical-epistemological, methodological, pedagogical, etc.) of existing semantic fields of fundamental (key) concepts in the context of a system of principles formulated for a specific scientific field. The basic concepts underlying the semantic matrix 
are distributed by us, in accordance with the classification of V. E. Shukunov and V. F. Vzyatyshev in four spheres: 1. Science of the interaction between nature and society. 2. Philosophy of environmental education. 3. Pedagogical ecology. 4. Theory and practice of environmental education, which form the fundamental basis for the development of environmental education.

The science of interaction between nature and society provides a scientific understanding of the laws of interaction between man and nature, being specified at the level of the following principles: synergy (which determines the wide application of synergetic ideas in scientific knowledge); organismic-oriented vision (approach to nature as a whole living organism); instability in development (understanding instability, disequilibrium as a factor in the development of systems); mathematization of natural science theories (the study of natural and social objects based on a mathematical model); countdown (defines the inclusion of the idea of limited time in the context of the problem of interaction between nature and society).

The philosophy of environmental education substantiates the need for a new concept of man's place in the biosphere, the ecological meaning of his existence, the social role of ecological education in solving global problems of mankind. The philosophy is revealed in the following principles: philosophizing (transferring the "consciousness-matter" problems from the philosophy in the context of ecology and environmental education); integrity (awareness of the need for a global comprehensive view of the world); coevolution (paired, interdependent changes of systems or parts within the whole); the principle of global evolutionism (associated with the desire to build a general scientific picture of the world on the basis of universal evolutionism, which combines the ideas of systemic and evolutionary approaches).

Pedagogical ecology is a model of interaction between people within the system of environmental education and with the system of environmental education itself. The principles underlying it are: interdisciplinarity (determines the change in the nature of the object of research in general and applied ecology, the strengthening of the role of interdisciplinary integrated approaches in its study); anthropo-ecology (determines the inclusion of environmentally oriented human activities in the field of pedagogical ecology); methodological pluralism (awareness of the limitations, one-sidedness of any methodology); extra-rationalism in the knowledge of nature (weakening of requirements for strict standards of scientific knowledge due to the extra-rational component).

The theory of practice of environmental education makes it possible to present the appearance of a new system of environmental education: to determine the goals, structures, systems, principles of its organization and management. It is based on the principles of formation of the content of general education (V. V. Kraevsky) and the idea of a systematic methodology of environmental pedagogy (A.V. Petrov, R. V. Oparin): humanization (involves addressing the individual through the prism of ecology); «fundamentalization» (the idea of integrating humanitarian and natural science knowledge); the priority of universal values (directed against excessive indoctrination and absolutism of any one position in the solution of environmental problems); pragmatism in shaping the content of environmental education (the account not only state interests but also the interests of the individual in determining the content of environmental education); flexibility (provides variability of the content of environmental education depending on specific conditions); active orientation (communication of requirements to knowledge and skills of the trainees with the contents of their activities); adaptability (taking into account technologies of transfer and assimilation of environmental education in determining its content).

We started the theoretical level of research on the problem of technological support for continuous environmental education by highlighting its essence at the conceptual level. The analysis of scientific publications over the past two decades leads to the conclusion that 
common scientific approaches adopted by all scientists to the disclosure of the essence of technological support for the educational process have not yet been developed.

Consideration of the essential characteristics of the concept of "technological support for continuous environmental education" requires an analysis of the concept of "pedagogical technology", determining its main parameters necessary for building a model of technological support for continuous environmental education (Figure 1).

According to our position, technological support is not just the use of teaching tools. It is the identification of principles and development of methods for optimizing the educational process using modern technologies that increase educational efficiency, as well as through the diagnosis of the effectiveness of the methods used.

Logical-semantic and logical-structural analysis of the concept of "technological support" allowed us to determine the content of its structural blocks in relation to the technological support of continuous environmental education. In the context of a structural and logical approach, we define "technological support for continuous environmental education" as a pedagogical system that includes two independent and at the same time interrelated and mutually complementary components - organizational and pedagogical, which are revealed through a technological component.

The organizational unit includes a set of tools, forms, and methods for organizing the process of environmental education. The pedagogical block is represented by a set of methods and techniques of training and education carried out in the educational and extracurricular areas of environmental education at all stages of pre-school, school, and post-school education.

As a technological component that provides the procedural side of continuous environmental education, it is proposed to consider the use of modern learning technologies in the educational process.

A comprehensive study of such general scientific categories as "system", "structure", "function", "model", "modeling" served as a prerequisite for building a structural and functional model of technological support for continuous environmental education. Based on the theory of pedagogical systems and the theory of pedagogical design, the structural and functional model was defined by us as a set of interrelated structural and functional components that are subordinate to the goals of environmental education and upbringing. Its main characteristics were integrity, interconnectedness of elements, connection with the environment. 


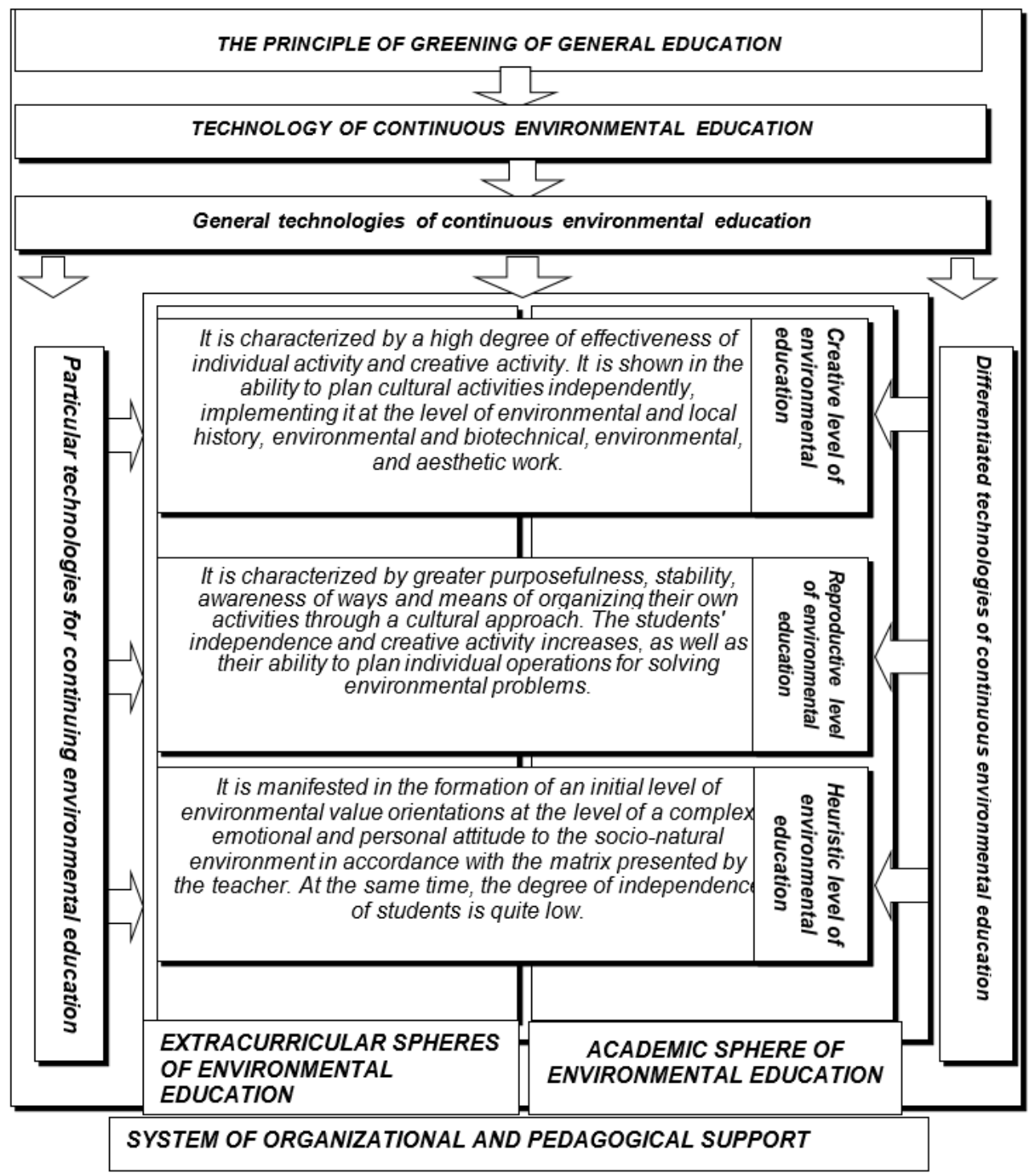

Fig. 1. The principle of greening of general education.

The theory of pedagogical systems helped to identify the structural and functional components of the system of technological support for environmental education, and the theory of pedagogical design helped to outline its structure and principles of organization.

The starting point in the development of structural-functional model of the system of technological provision of continuous ecological education was the hypothesis that the efficient and stable operation can be ensured by the presence of such key terms as: dynamism, ensuring the development of environmental concepts through a set of forms and means of environmental education in the academic and extracurricular field; the predictability of determining the ability of diagnosis and evaluation of indicators of environmental training and education of students; continuity, which involves a system of continuous environmental education, covering both academic and extracurricular areas.

The main structural components of the project are the concept of continuous environmental education and the principle of environmental education, which determine the 
basic characteristics of the system of technological and didactic support for continuous environmental education. The functioning of this system is carried out at the expense of its two basic components: forms and means of environmental education in the educational and non-educational spheres. In the educational sphere, forms of environmental education are represented by lessons, extracurricular and extracurricular activities, environmental workshops. The corresponding tools are represented by educational and methodological materials, natural and visual tutorialı, and technical training tools. In the extracurricular sphere, forms of environmental education are represented by environmental actions, environmental campaigns, environmental education events. The means are represented by environmental expositions, environmentally oriented mass media, popular science literature. The interconnection of educational and extracurricular spheres of environmental education is provided by such technologies as the Internet and multimedia, which are both forms and means of environmental education.

\section{Results}

Ecological education as leading principle of the education system is concretized at the level we have developed the concept of development of continuous ecological education in the Republic of Altai (hereinafter - the Concept), the purpose of which is to develop scientifictheoretical basics of ecological education system in the region. The purpose of this concept is to develop a regional mechanism for achieving this goal by means of scientifically based educational technologies that consider the regional cultural, economic, national, environmental, and educational features of the Altai Republic.

The mechanism for implementing the Concept is the technology of continuous environmental education, which is a systematic method of planning, implementing and monitoring the entire process of environmental education, which aims to optimize the forms and means of its implementation in specific pedagogical conditions.

Since in the conditions of realization of the Concept and technology of continuous environmental education the functions of the teacher become greatly enhanced and complicated, the development of a new model of training of future teacher as a graduate, integrated in the ecological culture and ecologically oriented, capable to device his own private life and lives his students, become more actual. From this position, the following areas of activity, main functions and over-subject skills of the future teacher in the framework of environmental education technology are defined: 1) strategic educational activities; 2) theoretical-methodological and epistemological activities; 3) ecological education and environmental education activities; 4) research activities related to the organization of monitoring results of environmental education; construction and design work on the development of methods and technologies for environmental education; 6) theoretical and practical activities; 7) organizational activities of a methodologist, an organizer of additional education and a public leader in optimizing and managing innovative processes within the framework of environmental education technology; 8) pedagogical practice, i.e., activities that ultimately embody all the above hierarchically subordinated theoretical ideas.

Considering these areas of activity of the future teacher in the framework of environmental education technology, the nomenclature of environmental disciplines is defined. It can consist of five blocks: ecological-cultural (mastering the basics of ecological culture), ecological-psychological (development of ecological thinking and ecological consciousness in the context of environmental pedagogy and psychology), ecologicalhumanitarian (ecological-humanitarian and ecological-ethnic training), ecologicaltechnological (development of technologies and innovations in environmental education), ecological-creative (entering the school of scientific and ecological skills, creativity, 
development of environmental experience); environmental research (mastering the theory and technologies of research activities, specialization in scientific problems).

Essential to the effectiveness of the Concept of continuing environmental education is to assess the quality of environmental education. The toolkit for this is pedagogical monitoring, suggesting the presence of integrated system diagnostics, ongoing for a long time.

Based on research by I. D. Zverev, N. F. Vinokurova, S. V. Zakharova, L. V. Moiseeva, we propose to consider as a starting point in assessing the results of continuous environmental education of the specificity of ecological culture of personality, based on the assumption that the leading component of environmental education, is a motivationalappraisal activities. We consider the main aspects of such activities to be motivational, cognitive, and activity based.

The correlation of the main categories of educational goals in the motivational, cognitive and activity areas allows us to identify the levels of development of the goals of continuous environmental education: 1) adaptive; 2) reproductive; 3) heuristic; 4) creative.

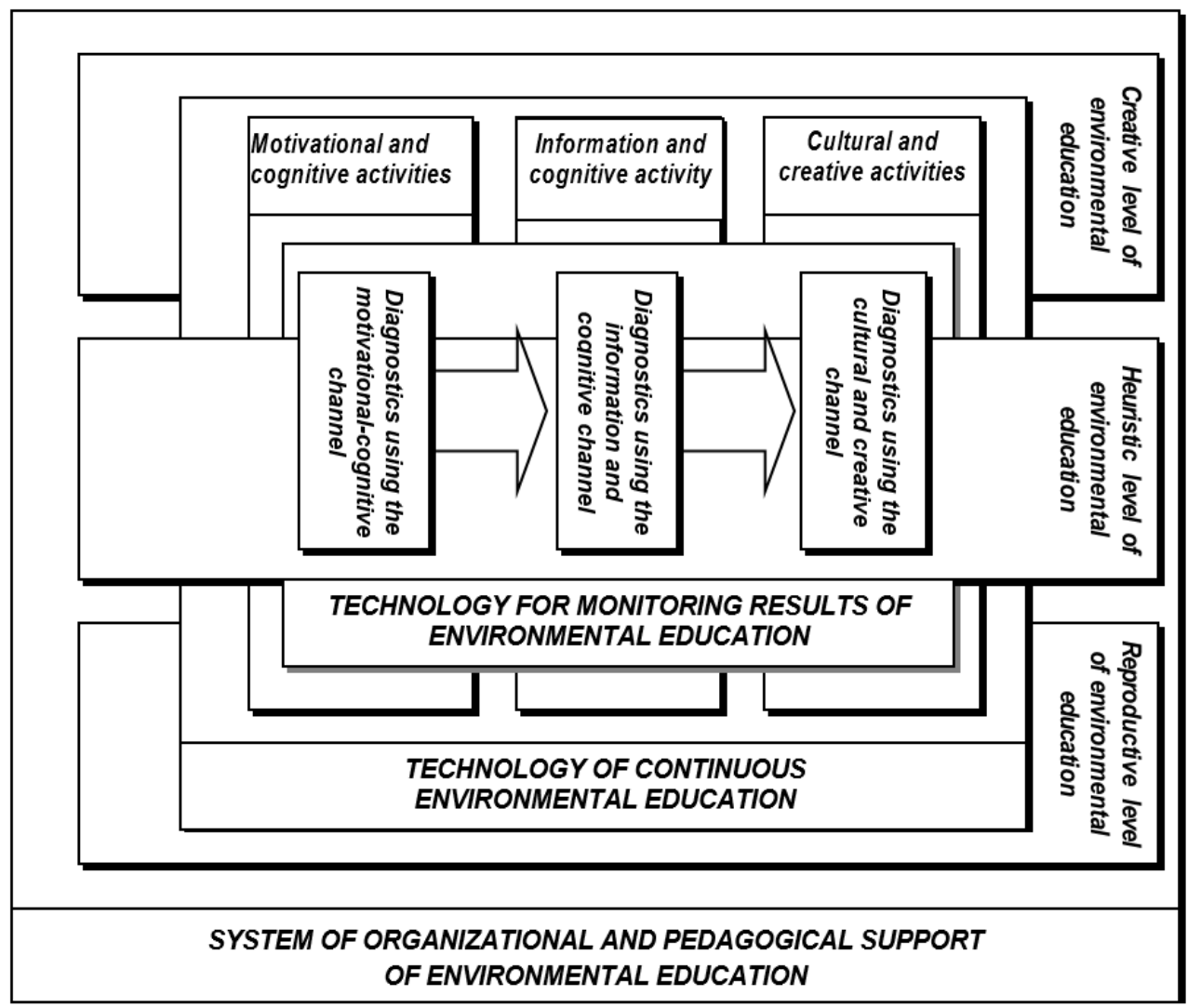

Fig. 2. Structural and functional model of the technological system ensuring continuous environmental education.

Based on the main target and content components of the concept of continuous environmental education, a motivational and evaluation technology for monitoring its results was developed (Figure 2). The specificity of this technology is that it allows not only to track the implementation of content-oriented components of the concept, but also to adjust them at each level of continuous environmental education.

Diagnostics in the system of higher and postgraduate education is equally important for 
the implementation of the technology of continuous environmental education. We have developed an occupation-chart technology for diagnosing the readiness of students as future teachers to implement the main functions of environmental education.

\section{Discussion}

When we started testing the theoretical model developed by us, we considered the fact that in different regions, under the influence of a set of conditions, continuous environmental education and its technological support system acquire their own characteristics. In the Republic of Altai, they are determined by natural-climatic, cultural-historical, socioeconomic specifics. The climatic specifics of the region determines the approach to environmental education from the point of view of the formation of the attitude to the nature of the Altai mountains as a world natural heritage, development of strategies and technologies environmentally benign interaction with her. The cultural and historical specificity of the region determines the approach to environmental education from an ecological and ethnic position, which implies an awareness of the need to preserve nature as a habitat for small ethnic groups. The socio-economic specifics of environmental education are related to the development of the "Altai - Golden Mountains" biosphere reserve and suggest strengthening its career guidance function in the light of the region's development prospects.

An analysis of the practice of environmental education in the Altai Republic has shown that the implementation of the technological component of environmental education can be traced in the activities of the Republican ecological and biological center of students (REBCS) as a coordinating center for continuous environmental education. Taking into account that the necessary condition for checking the effectiveness of any pedagogical project is its testing in specific conditions of the educational process, in the course of experimental work, the system of technological support for environmental education was introduced into the practice of this institution. The organizational block of the REBCS activity on technological support was implemented coordination of methodological work by managing the activities of teachers of the center, city, Republic in the field of additional environmental education, mobilization of students' activities, by organizing the work of the children's environmental organization "Svirel". Pedagogical component of REBCS activity for the organizational and pedagogical support of ecological education was revealed through the forms of learning, such as hobby club activity, environmental workshop, means of training teaching kits.

The main result of the experiment was the proof that the system of technological support for continuous environmental education of schoolchildren, developed on the basis of formulated conceptual provisions and hypotheses, creates conditions for the integral and effective assimilation of environmental knowledge by students, the formation of an environmental outlook and the wide use of environmental skills in practical educational activities of students.

Contradictions between the complexity of the subject of research, the difficulty of simultaneously identifying the effectiveness of all sides of the developed system of technological support were resolved by prolonged experimental work for ten years with the same contingent of students.

Due to the fact that the elements of the developed system had not been implemented in control (i.e. used for verification) classes and schools, and training there was conducted according to standard curricula and programs, the effectiveness of the System impact had to be judged by comparing the dynamics of the quality of knowledge and skills for leading curriculum and levels of ecological culture of teachers of the experimental and control classes. 


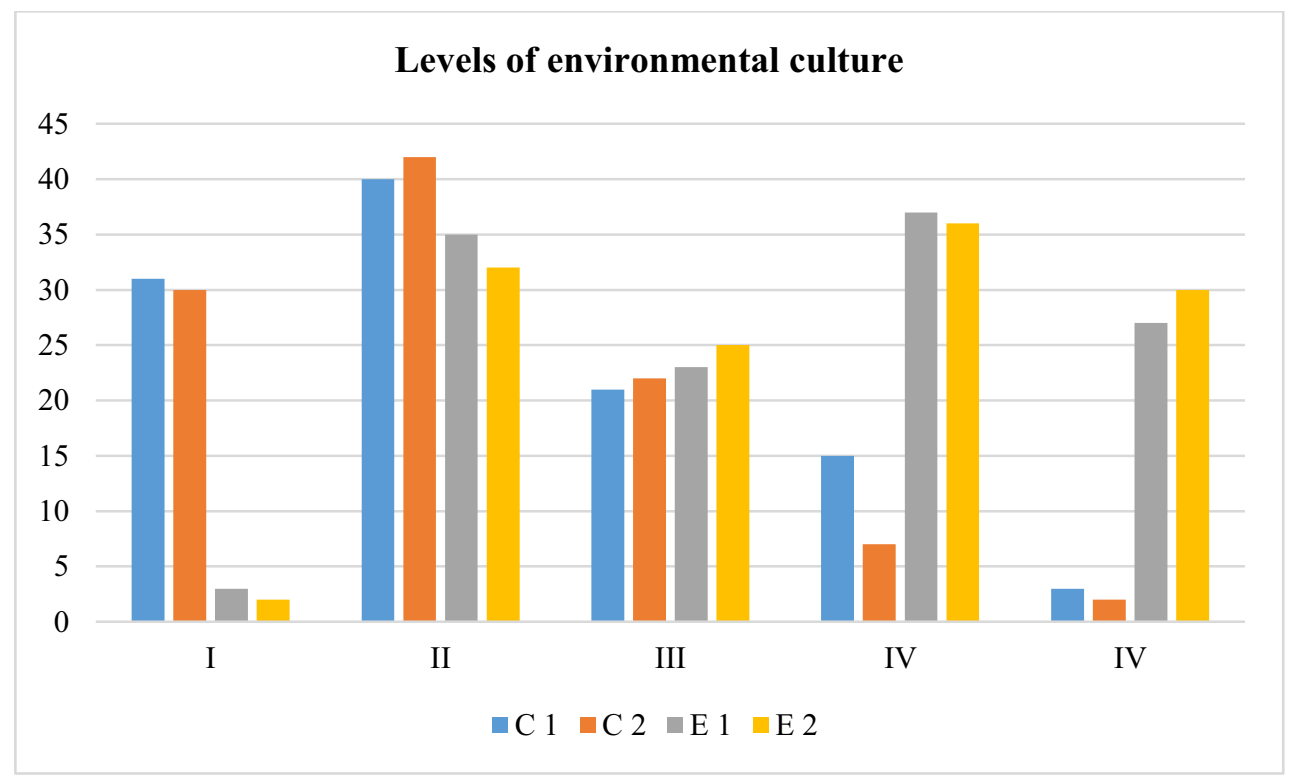

Fig. 3. Monitoring the effectiveness of the impact of the technological support system on the levels of environmental knowledge and skills of students of grades 1-11. Where: I - very low; II-below average; III-average; IV-above average; V-significantly above average.

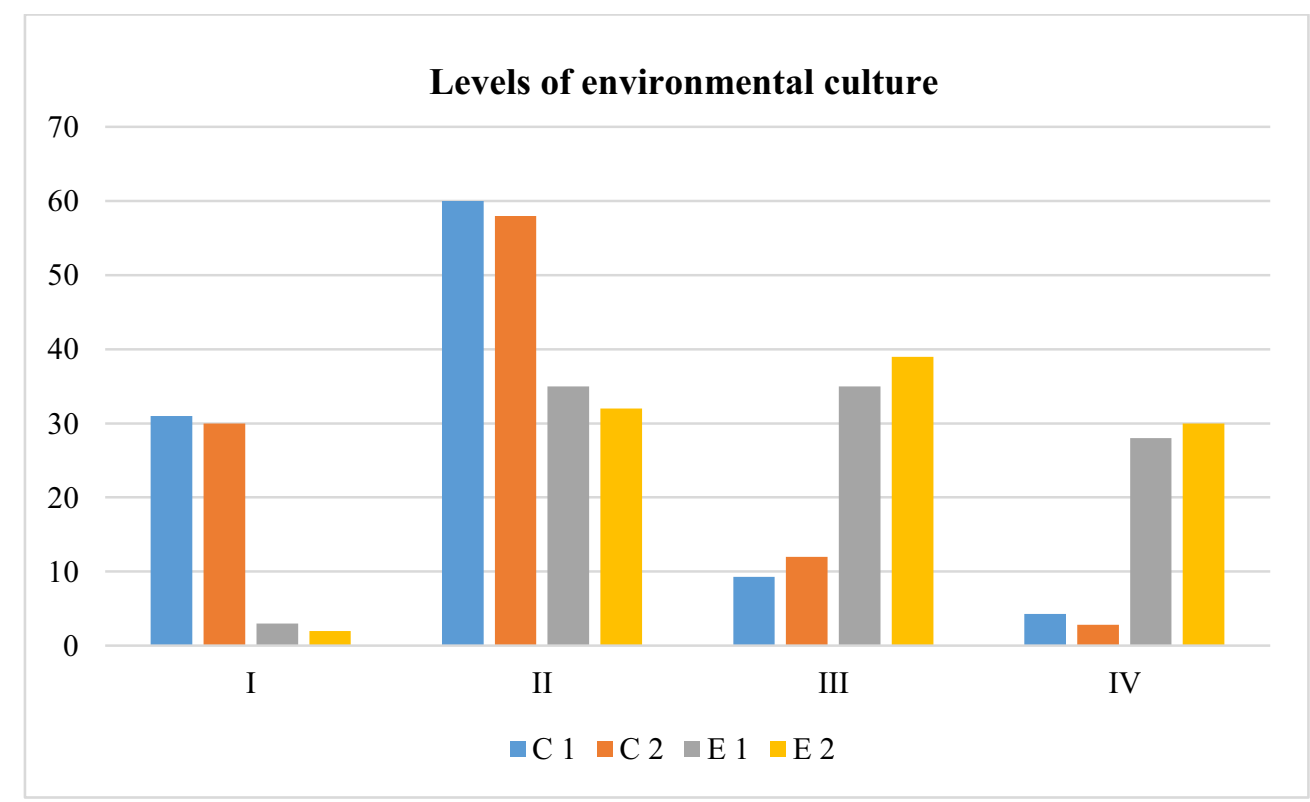

Fig. 4. Monitoring the effectiveness of the impact of the technological support system on the levels of environmental culture of students of grades 9-11. Where: I-invalid; II-critical; III-acceptable; IVoptimal.

The first three series of experiments showed a high efficiency of the impact of the technological support system on the success of school students' education to increase the level of their environmental culture. Thus, in a sample of groups of students in grades 1-11, the curves of the levels of knowledge, skills, and abilities in experimental classes are higher in the range of $14-46 \%$ than in control classes (Figure 3). 
High and above average levels of development of ecological culture the development of students in grades $9-11$ of the experimental group is from 39.3 to $41.2 \%$, while in the control group similar levels are from 34.5 to $35.6 \%$ (Figure 4 ).

The reliability of the experiment results was determined based on the consent criterion $\chi^{2}$ (Chi-square) with a significance level of 0.05 . This criterion is used to test hypotheses about the statistical significance of observed differences in the control and experimental groups at the initial and final stages of training. The results of calculations of the statistical criterion are presented in tables 1-2. The results show that $\mathrm{Tn}>\mathrm{Tk}$, which indicates the reliability of the results of our research.

Table 1. Monitoring the effectiveness of the impact of the technological support system on the levels of environmental knowledge and skills of students of grades 1-11.

\begin{tabular}{|c|c|c|c|c|c|c|c|c|}
\hline \multirow[b]{2}{*}{ Groups } & \multirow[b]{2}{*}{ Sample } & \multicolumn{5}{|c|}{ Levels of environmental culture } & \multirow{2}{*}{$\begin{array}{c}\text { Statistical } \\
\text { criterion } \\
T_{n}\end{array}$} & \multirow{2}{*}{$\begin{array}{c}\text { Statistica } \\
\text { criterion } \\
T_{k}\end{array}$} \\
\hline & & I & II & III & IV & $\mathbf{V}$ & & \\
\hline Control & & & & & & & \multirow{6}{*}{81.2} & \multirow{6}{*}{9.5} \\
\hline $\mathrm{C}_{1}$ & 103 & 31 & 40 & 22 & 8 & 2 & & \\
\hline $\mathrm{C}_{2}$ & 100 & 29 & 41 & 23 & 6 & 1 & & \\
\hline \multicolumn{7}{|l|}{ Experimental } & & \\
\hline $\mathrm{E}_{1}$ & 102 & 2 & 11 & 24 & 37 & 28 & & \\
\hline $\mathrm{E}_{2}$ & 102 & 1 & 10 & 25 & 36 & 30 & & \\
\hline
\end{tabular}

Table 2. Monitoring the effectiveness of the impact of the technological support system on the levels of environmental culture of students of grades 9-11.

\begin{tabular}{|l|c|c|c|c|c|c|c|}
\hline \multirow{2}{*}{ Groups } & \multirow{2}{*}{ Sample } & \multicolumn{4}{c|}{$\begin{array}{c}\text { Levels of environmental } \\
\text { knowledge and skills }\end{array}$} & \multirow{2}{*}{$\begin{array}{c}\text { Statistical } \\
\text { criterion } \mathbf{T}_{\mathbf{n}}\end{array}$} & $\begin{array}{c}\text { Statistical } \\
\text { criterion } \mathbf{T}_{\mathbf{k}}\end{array}$ \\
\cline { 3 - 6 } & & I & II & III & IV & & \\
\hline Control & & & & & & & \multirow{2}{*}{7.8} \\
\hline $\mathrm{C}_{1}$ & 103 & 31 & 60 & 9 & 3 & & \\
\hline $\mathrm{C}_{2}$ & 100 & 30 & 58 & 10 & 2 & & \\
\hline Experimental & & & & & & & \\
\hline $\mathrm{E}_{1}$ & 102 & 3 & 36 & 35 & 28 & & \\
\hline $\mathrm{E}_{2}$ & 102 & 2 & 34 & 38 & 29 & & \\
\hline
\end{tabular}

Experimental studies have shown that the most effective forms and methods in the system of technological support is the inclusion of schoolchildren in experimental activities of an environmental orientation. Thus, the quality of knowledge of students - "theorists" - in mathematics and natural science is $7 \%$ higher on average than that of students in the general experimental sample, and $21.2 \%$ higher than that of students in the control group. The quality of knowledge among students - "practitioners" - is on average $4 \%$ higher than in the general experimental group, and $25.9 \%$ higher than in the control group.

\section{Conclusion}

Based on the results of theoretical and methodological and practical research of the problem of its experimental verification, the following conclusions can be formulated.

1. Based on the theoretical, methodological, and practical aspects of environmental education, we have developed a concept of continuous environmental education that has a general character and is projected on a specific region - the Republic of Altai and a structural. We have developed a functional model of the system of technological support for the system of continuous environmental education of schoolchildren, which is based on 
the principle of environmental education with its content, regulatory and procedural functions. The study has confirmed the hypothesis that this concept is necessary and proved its effectiveness in terms of developing technology for continuous environmental education in the region. This concept, adopted by the Government of the Altai Republic, was the theoretical and methodological basis of this technology. Our Concept of environmental education in the Republic of Altai allows you to see the entire educational process as a whole and to take into account the connections between all functional structures most fully, since all of them are based on system, activity, reflexive, synergetic, resource, cultural approaches. Our Concept creates a theoretical basis for solving an important practical problem - the organization of scientific substantiation of the didactic base of environmental education. All this allows us to use the heuristic features of the Concept to predict the process of implementing innovative technologies of environmental education, to identify development prospects and to prevent possible problems and difficulties in experimental work.

2. The study proved that the pedagogical technology of continuous environmental education is an effective tool and mechanism for implementing the Concept of continuous environmental education in the Republic of Altai. The technology of continuous environmental education is a system that covers the planning, design, implementation and monitoring of the entire process of environmental education and aims to optimize the forms and means of implementing environmental education in specific pedagogical conditions. The main result of implementing the technology of continuous environmental education is a conscious socially significant activity aimed at harmonizing relations with the environment. The immediate result of implementing the technology of continuous environmental education should be an understanding of the need for not only environmental, but also socio-economic changes in environmental management in the world community, individual states, regions, localities, organizations and educational institutions) that strictly comply with environmental requirements.

The technology of continuous environmental education is implemented through training courses, their basic constructive component. However, given that the concept of sustainable development can play the role of a system-forming factor in the education system, it becomes possible to implement environmental education not in fragments, but in a systematic way. The technology of continuous environmental education seeks to actualize the process of training, education, self-development, self-realization, self-actualization on the development of independent, critical thinking, spiritually wealthy, socially active citizens, based their actions on the principles of environmental ethics and post-material values, seeking to obtain knowledge about the environment, caring about her condition, personally and in co-operation to help resolve existing and prevent new social, economic and environmental problems.

3. The theory and practice of environmental education have reliably shown that without an appropriate concept and system of technological support pedagogical technology cannot solve educational problems. Therefore, these structures are interconnected and mutually dependent. This relationship is presented in the work of the structural and functional model of the system of technological support for continuous environmental education, which is a set of structural and functional components in their interaction and interrelation. The main and leading structural component of the model is the technology of continuous environmental education. The implementation of it is provided by two basic components of the project: forms and means of environmental education in the educational and extracurricular spheres. In the educational sphere, forms of environmental education are represented by following item: lessons, extracurricular and extracurricular activities, environmental workshops; tools - educational and methodological materials, natural and visual tutorials, technical training tools. In the extracurricular sphere, forms of 
environmental education are represented by following item: environmental actions, environmental campaigns, environmental education events; means-environmental expositions, environmentally oriented mass media, popular science literature. Modern technologies such as the Internet and multimedia, which are both forms and means of environmental education, ensure the interconnection of educational and extracurricular areas of environmental education.

The regional-oriented program and methodological complex is also a means of implementing the system of technological support for continuous environmental education in the Republic of Altai.

The results of the experiment confirmed that the system of technological support for continuous environmental education developed on the basis of the formulated conceptual provisions and hypothesis creates conditions for the integral and effective assimilation of environmental knowledge by students, the formation of environmental culture and the wide use of environmental skills in practical educational activities of students.

4. The research allows us to explain the essence and predict the development of complex processes in the field of education; to use the experience of theoretical substantiation of the introduction of didactic provisions in the rank of teaching principles and the experience of developing their "instrumentality" (method of application) in the form of content, normative and procedural didactic functions; to build a concept that creates a theoretical basis for solving important practical problems in the education system and use the experience of revealing the deeper content of previously known pedagogical concepts, which allows to identify their new essential features.

\section{References}

1. UN Conference on environment and development (Rio de Janeiro, 1992) https://www.un.org/ru/documents/decl_conv/declarations/riodecl.shtml

2. Altajskij, Katunskij zapovedniki, Zona pokoya «Ukok», oz. Teleczkoe, g. Beluxa (Komissiya Rossijskoj Federacii po delam YuNESKO) $\mathrm{http}: / /$ unesco.ru/ru/?module= objects\&action= view\&id=12

3. V.A. Cherkasov, Mezhpredmetny'e svyazi kak neobxodimee usloviya povy'sheniya kachestva podgotovki uchitelya fiziki v pedagogicheskom vuze: Mezhvuz. sb. nauch. tr. (Chelyabinsk, ChGPI, 1981)

4. M.E. Duranov, Puti povy`sheniya e`ffektivnosti obucheniya v shkole (Chelyabinsk, ChGPI, 1977)

5. U.A. Radzhabov, Dinamika estestvenno-nauchnogo znaniya: Sistemnometodologicheskij analiz (M., Nauka, 1982)

6. A.V. Petrov, R.V. Oparin, Sistemnaya metodologiya e`kologicheskoj pedagogiki: Nauchno-metodicheskoe posobie dlya prepodavatelej i uchitelej (Gorno-Altajsk, PANI, 2007)

7. R.V. Oparin, Vestnik tomskogo gosudarstvennogo universiteta 115, 99 (2006)

8. R.V. Oparin, Vestnik Tomskogo gosudarstvennogo universiteta 115, 105 (2006)

9. R.V. Oparin, Vestnik Chelyabinskogo gosudarstvennogo pedagogicheskogo universiteta. Seriya 2. Pedagogika. Psixologiya. Metodika prepodavaniya 14, 93 (2006)

10. R.V. Oparin, Mir nauki, kul `tury` i obrazovaniya 3(10), 181 (2008)

11. R.V. Oparin, Mir nauki, kul 'tury` i obrazovaniya 4(11), 93 (2008)

12. R.V. Oparin, Mir nauki, kul `tury` i obrazovaniya 2(14), 133 (2009)

13. R.V. Oparin, Mir nauki, kul `tury`i obrazovaniya 2(14), 192 (2009) 
14. R.V. Oparin, Mir nauki, kul`tury` i obrazovaniya 3(15), 115 (2009)

15. R.V. Oparin, Organizacionno-pedagogicheskie osnovy`e kologicheskogo obrazovaniya : monografiya (Moscow, Bely`e Al'vy', 2004)

16. R.V. Oparin, Koncepciya neprery vnogo e’kologicheskogo obrazovaniya v Respublike Altaj i ee texnologicheskoe obespechenie (Gorno-Altajsk, PANI, 2007)

17. R.V. Oparin, Programmno-metodicheskoe obespechenie koncepcii neprery vnogo e kologicheskogo obrazovaniya v Respublike Altaj (Gorno-Altajsk, PANI, 2006)

18. R.V. Oparin, Koncepciya razvitiya neprery vnogo e’kologicheskogo obrazovaniya $v$ Respublike Altaj (Gorno-Altajsk, PANI, 2006)

19. R.V. Oparin, E`kologicheskoe obrazovanie v Respublike Altaj: teoreticheskie $i$ organizacionny'e aspekty`: monografiya (Vashington-Novosibirsk, Mezhdunarodny’j izdatel`skij centr fonda «Global-Grin-Grants», 2005)

20. R.V. Oparin, Texnologiya neprery vnogo e kologicheskogo obrazovaniya: teoreticheskie $i$ metodicheskie aspekty : monografiya (Vashington-Novosibirsk, Mezhdunarodny`j izdatel'skij centr fonda «Global-Grin-Grants», 2007)

21. R.V. Oparin, Sistemnaya metodologiya e`kologicheskoj pedagogiki: nauchnometodicheskoe posobie dlya prepodavatelej i uchitelej (Gorno-Altajsk, PANI, 2007)

22. T.M. Efimova, Problemy`e kologii i e’kologicheskogo obrazovaniya: sostoyanie, puti resheniya: Po materialam Vserossijskoj nauchno-prakticheskoj konferencii (Krasnoyarsk, 1998)

23. E.N. Arbuzova, V.I. Loshenko, R.V. Oparin, A.V. Saxarov, Metodika obucheniya biologii. Dlya podgotovki kadrov vy`sshej kvalifikacii: uchebnoe posobie dlya vuzov (Moscow, Izdatel'stvo Yurajt, 2019)

24. E.N. Arbuzova, R.V. Oparin, Biologiya v shkole 6, 22 (2019)

25. T.M. Efimova, Biologiya kak osnova formirovaniya u uchashhixsya znanij i priemov racional nogo prirodopol zovaniya: dissertaciya kandidata pedagogicheskix nauk (Moscow, 2000) 